Makale türü / Article type: Araştırma / Research

\title{
Öncü Düşünürlerinin Yaklaşımları Çerçevesinde Postmodern Sosyal Teoriye Yönelik Eleştirel Bir Analiz \\ ****
}

\section{A Critical Analysis Towards Postmodern Social Theory Based On the Approaches of Its Leading Thinkers}

\begin{abstract}
Arş. Gör. Dr. Orçun Girgin
Kütahya Dumlupınar Üniversitesi, Fen-Edebiyat Fakültesi, orcungirgin@gmail.com

Özet

Modernliğin sona ererek postmodern bir tarihsel çağın başladığını öne süren postmodernizm, sosyal teori gelenekleri arasında radikal bir yaklaşımı temsil etmektedir. Postmodernizmin meta anlatıların çöktüğüne, yaratıcı öznenin öldüğüne, anlam düzeninin yıkıldığına ve üretim biçiminde köklü değişikliklerin meydana geldiğine ilişkin tezleri, aslen, modern yaşamı örgütleyen ilkelerin ortadan kalktığı iddiasına dayanmaktadır. İlkelerin yerini farklılıkların alması karşısında, insanların bir araya geldiği ortak zemin olarak toplumun da sona erdiği kabul edilmektedir. Postmodernizm, bu bağlamda, yeni bir ilişkiler ağının ortaya çıktığını ilan etmektedir. Bununla birlikte, postmodern teorisyenler ortaya çıktığını öne sürdükleri yeni insanlık durumuna yaklaşımları konusunda birbirlerinden ayrılmaktadır. $\mathrm{Bu}$ çalışma, postmodern teorinin üç öncü isminin düşüncelerini irdeleyerek, postmodernizmin temel iddialarını eleştirel bağlamda tartışacaktır.
\end{abstract}

Anahtar Kelimeler: Modernlik, Postmodernizm, Modernliğin Sosyolojisi, Sosyal Teori, Toplumsal Değişme.

\section{JEL Sınıflandırması: Z00}

\begin{abstract}
The thesis of postmodernism about the collapse of meta-narratives, the death of creative subject, the destruction of the established order of meaning and the radical transformations in the production form are actually depend on the argument that the principles which organize the modern life has been abolished. It is assumed that the society as the common ground of collective action has itself been dissolved in this process of replacement of principles by differrences. In this context, postmodernism announces the emergence of new networks of relations. However, postmodern
\end{abstract}


theoreticians disagree in their approaches to the new human condition that they assert has emerged. In this article, the thoughts of three leading figures of postmodern theory will be analyzed and the basic arguments of postmodernism will be discussed in a critical perspective.

Keywords: Modernity, Postmodernism, Sociology of Modernity, Social Theory, Social Change.

JEL Classification: Z00

\section{GÍRIŞ}

1970'lerin sonunda sosyal bilimlerde çağdaş sosyal dünyanın çözümlenmesine yönelik yeni bir yaklaşım ortaya çıkmıştır. Bu yaklaşım, 1950'lerde ortaya konulan modernleşme kuramının ${ }^{1}$ analizleri dışında, sosyal bilimlerde genel olarak ihmal edilen modernlik kavramını tartışmaya açmıştır. O döneme kadar sosyal dünyaya ilişkin çalışmalar genel olarak modernlik kavramını analizlerinin odağına yerleştirmeyi tercih etmezken, bunun yerine, modern dünyanın ekonomi, kültür gibi özgül sahaları üzerine yoğunlaşmışlardır. Bu dönem ile birlikte, bütün sahaları kapsayan bir bütünlük olarak modernliği tartışmalarının merkezi kavramı olarak kullanmaya başlayan postmodernizm yeni bir perspektif olarak doğmuştur.

Postmodernizm modernlik kavramını analiz teması olarak alırken, kendi iddiasını modernliği fiili bir gerçeklik olarak olumsuzlaması üzerinden ortaya koymaktadır. Bu bağlamda, postmodern teori modernliğin tarihsel bir çağ olarak sona erdiği iddiası taşımaktadır. Modernliğin aşılması sonucu "postmodern" bir çağ ile karşı karşıya olduğumuz ileri sürülmektedir. 1980’lerde yükselişe geçen bu düşünce akımı, bazı düşünürler arasında, içinde yaşadığımız dünyanın postmodern olduğuna yönelik bir konsensüsü ortaya çıkarmışıır². Bu çalışma insanlık tarihinde yeni bir çağın varlığına işaret eden söz konusu teorik anlatının içerimleri üzerine odaklanacaktır. Bunun için öncelikle postmodernizmin sosyal bilimler içinde gelişimi tarihsel süreç içinde ortaya konulmaya çalışılacaktır. Bunun ardından, postmodern teorinin öncü düşünürleri arasında yer alan Lyotard, Baudrillard ve Jameson'ın argümanları eleştirel bir perspektifle ele alınacaktır. Sonuç bölümünde de

\footnotetext{
${ }^{1}$ Modernleşme kuramının temel argümanları için bkz. Eisenstadt, 2007.

${ }^{2}$ Postmodern bir çağa geçildiği iddiası Vattimo (1999) ve Rorty'de (2006) görülebilir.
} 
postmodernizmin çağdaş sosyal gerçekliğe dair açılımlarının günümüz dünyasına 1şık tutup tutmadığı değerlendirilecektir.

\section{POSTMODERNIZMIN GELIŞiMI}

Postmodernizmin sosyal teorideki tartışmaların gündemine oturması 1980'lerle birlikte başlamasına karşılık, kavram olarak "postmodern”in kullanımı 19. yüzyıla kadar geri gitmektedir. Postmodern terimi ilk olarak, İngiliz ressam John Watkins Chapman tarafindan, 1870'li yıllarda İzlenimci resimden daha modern bir resim türünü tarif etmek üzere kullanılmıştır. 1917 yılında yazar Rudolf Pannowitz, çağdaş Avrupa kültüründeki değerlerin çöküşünü betimlemek üzere postmodern terimini kullanır. Daha sonra tarihçi Arnold Toynbee, Avrupa medeniyetinin gerileyişini dönemselleştirmek üzere postmodern çağ nosyonunu kullanmıştır. Ancak Toynbee, sistematik bir postmodern çağ teorisi geliştirmek yerine Avrupa'daki özgül bir çalkantı dönemini anlatmak üzere, bu kavramı kullanmakla yetinmektedir. Postmodern terimi, 1940 'll ve 1950'li yıllarda zaman zaman yeni mimari ve şiir biçimlerini betimlemek üzere kullanılsa da 1960'lara kadar bugünkü anlamından epey uzaktır. Postmodern, asıl olarak 1960'lardan sonra edebiyat, şiir, resim ve mimarideki yeni biçimlerin oluşumu üzerine kültürel teori alanındaki tartışmalarla bugünkü anlamını bulmaya başlamıştır (Best \& Kellner, 1998).

Büyük ölçüde kültürel alandan kaynaklanan postmodern kavramı, 1970'lerle birlikte gittikçe yaygınlaşıp toplumun birçok alanını kapsar hale gelmiştir. Postmodern resim, mimari, edebiyat ve sinemanın yanında postmodern felsefe, politika, ekonomi, aile ve kişiden de söz edilmeye başlanmıştır (Kumar, 1999). Bu dönemlerde çağdaş sanatçılar tarafından keşfedilen konuların kavramsal ifadesini Foucault ve Derrida gibi düşünürler tarafından temsil edilen post-yapısalcı felsefe sağlamaya başlamıştır. Postyapısalc1lık, gerçekliğin çoğul karakterini vurgulamak üzere kuruludur. Postyapısalcılık, kurumlar, söylemler ve metinlerin ardında yatan çoğul realiteyi ortaya çıkarmaya çalışır. Bunun yanında, Batı toplumlarının son yıllarda uğradığı varsayılan dönüşümleri ifade etmek üzere, Bell ve Touraine gibi sosyologlarca post-endüstriyel toplum kuramı ortaya atılmıştır. $\mathrm{Bu}$ kuramcılara göre, gelişmiş dünya endüstriyel üretime dayalı ekonomiden, 
sistematik kuramsal araştırmaya dayalı bir ekonomiye doğru, toplumsal ve kültürel yönleri olan bir geçişi yaşamaktadır. Bu çalışmaların sonucunda, postmodern sanat, post-yapısalcı felsefe ve post-endüstriyel toplum kuramının Lyotard tarafindan bir araya getirilmesiyle, sosyal teorideki postmodernist kopuşlar ilk ifadesini bulmuştur (Callinicos, 2001).

Kuram olarak postmodernizmin kökenleri daha gerilere götürülebilir. 2. Dünya Savaşı sonrası Avrupa'da çalkantıların durduğu, Sovyet rejiminin bürokratikleştiği bir ortamda işçi ayaklanmalarının başarısızlığ ile birlikte, sermayenin iktidarını yıkma yönündeki siyasal stratejiler zayıflamış, sermayenin dönüşümlerine ilişkin ekonomik çözümlemeler önemini yitirmeye başlamıştı (Anderson, 2002). Bu koşullarla birlikte 1968 hareketinin de ekonomiden ziyade kültürel taleplerle belirlenmesi sonucu, düşünürlerin bir bölümü toplumsal değişime yönelik umutlarını tamamen yitirdiler. Böylece, "bir toplum kuramı olarak postmodernizm 1968'de doğdu. Postmodernizm bir anlamda, dünyayı kendi algılayışından hayal kırıklığına uğrayan yabancılaşma kuşağının eseriydi” (Heller \& Feher, 1993, s. 200).

1968'deki yenilgiden sonra Marksizmden kopanlar, başarısızlığın gerekçesini modernliğin programına bağlamaya başlamıştır. 1980'lerde postmodernizmin teorik konumunu netleştirmesiyle birlikte bu düşünürler modernliğin başarısız olduğu ve postmodern bir çağın başladığı düşüncesinde buluşmuşlardır. Yine de postmodernistler arasında birtakım ayrılıklar mevcuttur. Postmodernistlerin bir kısmı varlığını onayladıkları yeni tarihsel dönem hakkında karamsar bir tablo çizerken, bazı postmodernistler de yeni çağ1 özgürleşme olarak görüp selamlayabilmektedir. $\mathrm{Bu}$ noktada, postmodernizmin önde gelen bazı teorisyenlerinin düşüncelerinin irdelenmesi konuya açıklık getirecektir. Bu teorisyenlerin başında, Lyotard, Baudrillard ve Jameson gelmektedir. Lyotard postmodern çağı ilan eden ilk düşünür olarak sosyal teoride yeni bir akımın başlamasına öncülük etmiştir. Dolayısıyla Lyotard bir yandan postmodern teorinin genel çerçevesinin oluşturulmasında başrolü oynarken, bir yandan da postmodernliğin bir özgürleşme çağı olarak tanıtılmasında en önemli figür olmuştur. Baudrillard ise postmodern döneme geçildiği konusunda Lyotard ile hemfikir olmakla birlikte, analiz ettiği dönemi öznenin çöküşü ve kitlenin egemenliği ile karakterize ederek karşıt bir bakış açısını temsil etmektedir. Jameson ise postmodern duruma Marksist bir 
çözümleme ile ulaşmakta ve ele alınan dönemi övmek ya da yermenin ötesinde, postmodernliğin kaçınılmaz bir gerçeklik olduğunu temellendirmeye çalışmaktadır. $\mathrm{Bu}$ nedenle postmodern teorinin farklı perspektiflerini betimleyebilmek açısından Lyotard, Baudrillard ve Jameson'ın düşüncelerinin analiz edilmesi önem taşımaktadır.

\section{POSTMODERNIZMIN TEMSÍLCILERI}

\subsection{Jean-François Lyotard: Meta Anlatıların Sonu}

Postmodernlik kavramı, sosyal teoriye ilk kez Lyotard aracılığıyla girmiştir. 1979'da yayınlanan "Postmodern Durum” adlı kitabı bugüne kadar gelen modernlik-postmodernlik tartışmalarının temeli olmuştur. Postmodern Durum öncesinde erken postmodern çalışmaların ${ }^{3}$ adını koyamadığı postmodern teori, Lyotard'in eseri ile açılı̆ğa kavuşur.

Lyotard, çalışmasını toplumsal bir durumu adlandırmak yerine bilginin son dönemlerdeki durumunu betimleme gerekçesiyle sunar. Postmodern Durum kitabının konusu hakkında şunları yazmaktadır: "Bu çalışmanın nesnesi, son derece gelişmiş toplumlarda bilginin durumudur. $\mathrm{Bu}$ durumu tasvir etmek üzere postmodern kelimesini kullanmaya karar verdim" (Lyotard, 2000, s. 11). Bununla birlikte, Lyotard'in mevcut toplumsal durumu postmodern olarak kavramsallaştırma niyetinde olmasına karşın, güçlü argümanlar öne sürememe, dolayısıyla başarısız olma endişesi taşıdığı görülmektedir. Bunu, kitabın ek bölümündeki, postmodernin ne olduğunu açıklama girişiminin zayıflığı gözler önüne sermektedir: "Postmodern nedir? İmge ve anlatılamanın kurallarında ortaya atılan sorunların başdöndürücü incelenmesinde ne gibi bir yer işgal etmekte ya da etmemektedir? Şüphesiz modernin bir parçasıdır" (Lyotard, 2000, s. 156). Böylece, Lyotard, postmoderni yeni bir dönem olarak savunmak yerine modernliğin epistemolojik bir analizini yaparak onu reddetmeye yönelmektedir.

Böylece Lyotard, postmodernliğe giden yolda, modern bilgi yapılarını eleştirerek işe başlar. Lyotard'a göre, modern bilim gerçekliği aradıkça kendi oyununun kurallarını meşrulaştırmakla yükümlüdür. Modern bilim kendisini, öznenin özgürlüğü, zenginliğin yaratımı gibi meta-anlatılara gönderme

\footnotetext{
${ }^{3}$ Bu çalışmalar arasında Debord (1967/2006) ve Deleuze \& Guattari (1972/1990) sayılabilir.
} 
yaparak meşrulaştırır (Lyotard, 2000). "Sözgelimi, modern bilim kendisini hakikat, refah ve ilerlemeyi ürettiği iddiasının yanı sıra cehalet ve safsatadan sözümona kurtulma öyküsü çerçevesinde meşrulaştırmıştır" (Best \& Kellner, 1998, s. 204). Lyotard'in modern bilime yönelik eleştirisinin yoğunlaştığı nokta, bilimin modernliğin meta-anlatılarını meşrulaştırma görevi üstlendiğidir. Dolayısıyla, modernliğin kendisini diğer çağlara göre en üstün çağ olarak kabul ettirmesi bilimin söylemsel işlevi ile olanaklı hale gelmektedir.

Lyotard'a göre, bilim tek bilgi türü değildir ve bilgi bilime indirgenemez. Ancak bilim kendisi dışındaki bilgi türlerini reddederek, kendisini yaşamın açıklanmasında tek otorite ilan etmektedir. Lyotard'a göre, bilginin modern yapıları meta-anlatıları ifade eder. Meta-anlatılar totalleştirici bilgi iddialarından ibarettir. Modern bilgi yapısı, tekelcidir ve kendisi dışında kalan bilgi biçimlerine karşı hoşgörüsüzdür. Böylece Lyotard'a göre, bilimin bayraktarlığını yaptığı modern bilgi, farklı bilgi iddialarını yok saymaktadır (Lyotard, 2000).

Her türlü teorik anlatı Lyotard'ın benzer eleştirisine uğrar. Bunların başında sosyal teori gelir. Lyotard'a göre, son dönem teorilerinde toplum ya işlevsel bir bütün oluşturmakta ya da sınıflar halinde ikiye bölünmektedir. Geleneksel teori, birleştirici element düşüncesini sistem teorilerine ödünç vermiştir. Marksist ve eleştirel teori, bu uzlaşmadan kaçınarak kapitalist toplumdaki mücadelelere odaklanır. Ancak Lyotard'a göre, kapitalist ekonomi politiğin eleştirisi, sistem tarafından kendini programlamanın aracı olarak kullanılmaktadır. Marksizmin ekonomi politik çözümlemelerinin kapitalistler tarafından kapitalizmin devamlılığını sağlamak amacıyla önlem olarak kullanıldığı gerekçesiyle, Lyotard, Marksizmdeki sınıf çatışması ilkesinin radikalliğini kaybetme noktasına geldiğini düşünür. $\mathrm{Bu}$ nedenle Lyotard'a göre, eleştirel model teorik konumunu yitirerek bir ütopyaya dönüşmektedir. Böylece Lyotard, sosyal teorinin mutlak bilgi iddialarının çöktüğünü düşünür (Lyotard, 2000).

Görüldüğü gibi Lyotard'ın eleştirilerinin temelindeki teori, Marksizm'dir. Bununla birlikte, bütün teorileri totaliter olmakla suçlar. "Lyotard'ın 'totaliteye karşı savaş'1, (...) birleştirici şemalar içerisinde farklılıkları bastırdıkları için 'teröristik' bir özellik barındıran ana anlatılar 
olarak betimlediği totalleştirici teorileri reddeder" (Best \& Kellner, 1998, s. 211). Lyotard, böylece sosyal teorinin tepeden inmeci bir bakışla toplumsal yaşamın farklılıkları içeren zenginliğini yadsıyarak, sosyal gerçekliği eksik tanıttığını ileri sürmektedir. Bir başka deyişle, sosyal teori toplumsal dünyayı temsil edememektedir.

Böylece, Lyotard'in temel hedefinin felsefe ve sosyal teori olduğu ortaya çıkmaktadır. Lyotard "bilim aracılığıyla insanlığın ilerlemeci özgürleşime ulaşabileceği ve evrensel olarak geliştirilmiş geçerli bilgiyi öğretebilmek için gereksinim duyulan birliği insanlığa felsefenin sağlayabileceği düşüncesine kesin bir dille saldırır" (Sarup, 2004: 188). Ancak Lyotard, bu noktada basit bir genelleştirme hatası yapmaktadır. Aydınlanma'nın bilimleri ve onların teorik açıklamalarına saldırmak uğruna, modern teorileri ortak bir noktada düzlemekte, sosyal teoriyi Marksizmle eşitlemektedir. "Lyotard 'büyük anlatılar' in hepsini bir araya yığmaya eğilimli olup, böylece kültürümüzdeki teorik anlatı çeşitliliğini tahrif etmektedir" (Kellner, 2000, s. 384).

Lyotard'a göre, bilimleri meşrulaştırma işlevi gören teorik metaanlatıların günümüz koşullarında inandırıcılığı kalmamıştır: "Hangi birleştirme türünü kullandığına ve spekülatif ya da bir özgürleşim anlatısı olup olmadığına bakılmaksızın, büyük anlatı güvenilirliğini kaybetmiştir" (Lyotard, 2000, s. 85). Lyotard, meta-anlatıların çöküşünü, 2. Dünya Savaş1 sonrası teknolojinin ilerlemesi ile insan eyleminin amaçlardan araçlara kanalize oluşu ve Keynesçilik sonrası liberal kapitalizmin yeniden canlanmasının etkisi ile açıklar. $\mathrm{Bu}$ dönüşümler, komünizmin ortadan kalkması ve mal ile hizmetlere karşı bireysel ilginin artması ile sonuçlanmıştır. Kapitalist yenilenme ve refah ile teknolojinin bozucu dalgalanması, meta-anlatıların sonunu getirmiștir (Lyotard, 2000).

$\mathrm{Bu}$ noktada Lyotard, postmodern durumun ortaya çıkışını, metaanlatıların çöktüğü iddiası ile gerekçelendirir:

Postmodern'i meta-anlatılara yönelik inanmazlık olarak tanımlayacağım. Bu inanmazlık kuşkusuz bilimlerdeki ilerlemenin bir ürünüdür. Ancak bu ilerlemedir ki, akabinde, inanmazlığı öngörür. Meşruluğun metaanlatısal aygıtının eskimişliğine, en başta metafizik felsefenin ve geçmişte üzerinde yükseldiği üniversite kurumunun krizi karş1lık gelmektedir (Lyotard, 2000, s. 12). 
Böylece, bilimsel araştırma sahası olan üniversite ile Lyotard'ın bilimin meşrulaştırıcı gücü olarak gördügü felsefe ve sosyal teori, Lyotard'ın iddiasına göre, modernliğe özgü işlevlerini yerine getirememekte; dolayısıyla postmodern bir döneme kapı aralanmaktadır. Bununla birlikte, Lyotard metaanlatıların nasıl çöktüğü ve bu çöküşün toplumsal sonuçlarına ilişkin tezlerini temellendirmemektedir. "Lyotard, bu teorik çöküşün nasıl ve niçin cereyan ettiğini ve kendisinin bu söylemlere karşı niçin polemiğe girdiğini anlatmaksızın, postmodernizmin büyük anlatılara 'karşı kuşkuculuk'u, büyük anlatıların 'dağılması'nı ve tüm meta-anlatıların meşruiyetlerinden arındırılmasını içerdiğini tekrar tekrar iddia etmektedir” (Kellner, 2000, s. 383).

Habermas'ın modernliğin sorunlarının rasyonel öznelerin iletişime geçerek konsensüse ulaşmaları sonucu çözülebileceği iddiası ${ }^{4}$, Lyotard tarafından reddedilir. Lyotard, uzlaşımın tartışmanın tekil bir durumu olduğu ve farklılıklara karşı şiddet uygulayacağı kanısındadır. Aksine, uzlaşım ereğine bağlı olmayan bir adalet pratiğine ulaşılmasını amaçlamayı savunur. Bu konuda başvurduğu yöntem, dil oyunlarıdır (Lyotard, 2000). Dil oyunları bireyleri ortak noktada buluşturmak yerine, farklılıkları serbest bırakır: "Dil oyunlarının farklı biçimliliğinin tanınması bu yöndeki ilk duraktır. Bu açıkça, dil oyunlarının eşbiçimli olduğunu varsayan ve öyle yapmak için uğraşan terörün bir reddini göstermektedir" (Lyotard, 2000, s. 141).

Lyotard'ın konsensüsü terörle eşdeğer görmesi, gerçekçi bir bakış açısından uzaktır. Konsensüs, bazı durumlarda baskıcı olabilmesine karşın ${ }^{5}$, daha çok sorun çözmeye ve özgürleşmeye dayalıdır. Lyotard'ın dille kurduğu toplumsal bağda, konuşmak, savaşmak anlamı taşır. Oysa konuşmak, tartışmanın yanı sıra iletişim kurmak, karşı1ıklı anlaşmaya varmak ve düşünce birliği oluşturmaktır (Best \& Kellner, 1998).

Buradan, Lyotard'ın modernlikten özgürleşmeye çalıştığı anlaşılmaktadır. Modernliğin sorunlarına çözüm aramak yerine, bütünüyle modernliğin dışına çıkarak yeni ve kaotik bir dünyaya göz kırpmaktadır. Rorty

\footnotetext{
${ }^{4}$ Bkz. Habermas, 2001.

5 Örneğin, Nazi Almanya'sında totaliter iktidar etrafında kümelenmiş baskıcı bir toplumsal konsensüs vard1.
} 
gibi postmodernist bir düşünür bile, Lyotard'ın bu düşüncesine karş1 çıkmaktadır:

Çocuklarımızın gelecekte nasıl olup da daha iyi bir dünyada yaşayabilecekleri hakkında önerilerde bulunmaktan ziyade 'şimdinin tarihini' yazmak yalnızca ortak bir insan doğası ve 'özne' nosyonundan değil, ama aynı zamanda bizim teorik olmayan toplumsal dayanışma duygumuzdan da vazgeçer. Sanki, Foucault ve Lyotard gibi düşünürler 'öznenin' bahtına ilişkin bir meta-anlatıya daha yakalanmaktan o denli çekinmektedirler ki, ait oldukları kuşağın kültürüyle özdeşleşmeye yetecek denli 'biz' demeye dilleri varmıyormuş gibi görünmektedir. Lyotard'ın 'özne felsefesi'ne duyduğu tiksinti, Habermas'ın Blumenberg ve Bacon'la paylaştığı 'özgürleşimin meta anlatısı' kokan her şeyden kaçınmasına yol açacak derecededir (Rorty, 2000, s. 277).

Lyotard'a göre, günümüz toplumlarında iletişim imkanlarının gelişmesiyle dil yeni bir önem kazanmıştır. Bu süreçte yeniden üretim işlevleri idarecilerden makinalara devredilmektedir. İçinde yaşadığımız toplum, bilgisayarlaşmış bir toplumdur. Bu koşullarda, dil oyunları enformasyon oyunları anlamına gelir. Bilgi, artık uzmanın kontrolünde kitlelerin enforme edilmesiyle değil, dil oyunları şebekesi içinde özgürce elde edilebilecektir (Lyotard, 2000). Böylece Lyotard'a göre, "postmodern bilgi otoritelerin basit bir aracı değildir. Farklılıklara olan duyarlılı̆̆ımızı arındırmakta, karşılaştırılamazlığımız, hoşgörme yetimizi pekiştirmektedir. İlkesi, uzmanın homolojisi değil, yenilikçinin paralojisidir" (Lyotard, 2000, s. 13-14).

Farklılıkların özgürleşmesi ve bilginin uzmanların denetiminden kopmasını postmodern bir dönemin işaretleri olarak öven Lyotard, bu değişimlerin kapitalist üretim biçimini güçlendireceğini düşünür: "Bilginin son bir kaç on yıl içerisinde üretimin esas gücü olduğu yaygın bir şekilde kabul edilmektedir. Bu durum zaten yüksek derecede gelişmiş ülkelerdeki işgücü kompozisyonu üzerinde kaydedilebilir bir etkiye sahiptir" (Lyotard, 2000, s. 20). Böylece, Marksist geçmişe sahip Lyotard'in sosyalizmden umudunu kestiği ve kapitalizme karşı eleştirel bir bakıştan vazgeçtiği görülür. Aksine, Lyotard bilginin uzmanların kontrolünden bağımsızlaşmasının kapitalizmi güçlendireceğini öne sürerek, geç kapitalizmin savunusunu yapmaktadır.

Lyotard'ın analizinin başlıca çelişkisi, betimlediği yeni toplum biçiminin teorik bir açıklamaya ihtiyaç duymasına karşın, teoriyi reddetmesinden dolayı böyle bir girişimden kaçınmak zorunda kalmasıdır. Bir 
meta-anlat1 olmadan genel bir postmodernizm teorisi ortaya koymak imkansızdır. Çağdaş sosyal dünyayı açıklamak teorik bir işlemi gerektirir. Böyle bir işlem, ayrıntılı bir analiz ile birlikte tarihsel kırılmanın nasıl gerçekleştiğini açıklamak zorundadır. Ancak Lyotard, modernlikten postmodernliğe geçişin parametrelerini ortaya koyamamakta; kendisine ait bir postmodern teori geliştirmekte başarısızlığa uğramaktadır (Kellner, 2000).

Lyotard'ın sosyal teoriye en önemli katkısı, yeni bir düşünce geleneği olarak postmodernizmin öncülüğünü yapmış olmasıdır. Postmodern Durum'un yayınlanmasından itibaren, daha sonra adları postmodernizmle anılmaya başlayacak olan birçok önemli sosyal teorisyen söz konusu geleneğe katkıda bulunmuşlardır. Ancak postmodern bir çağın ilanı noktasında Lyotard'ın yaklaşımının zayıflığı aşikardır. Lyotard'ın salt modern bilgi yapılarının eleştirisi üzerinden gerçekleşen analizi postmodern çağın kabul edilmesi konusunda yetersiz kalmaktadır. Dolayısıyla, postmodernliği yeni bir çağ olarak tanıtma girişimi farklı yaklaşımlara ihtiyaç duymaktadır.

\subsection{Jean Baudrillard: Toplumsalın Sonu}

İnsanlık tarihinde modernlik sonrası bir döneme girildiğini savunan bir kuramc1, kuşkusuz, modernliğe özgü kurum, temsil mekanizmaları, örgütlenme ilkeleri gibi bazı göstergelerin ortadan kalktığını iddia edecektir. Baudrillard, modernliğe işlerlik kazandıran bütün boyutların sonunu işaretleyen radikal bir postmodernist düşünürdür. Baudrillard'ın "son"lar dizisi içinde politika-ideoloji, üretim, tarih, anlam, özne ve toplum gibi modernliğin birçok temel dayanağı bulunmaktadır.

Baudrillard, modernliğe ilişkin göstergelerin yok oluşunu, gerçeklik adlı zeminin artık var olmadığı iddiasına dayandırır. Bu iddiaya paralel olarak Baudrillard, varsayımlarının merkezine simülasyon kavramını koyar: "Bir köken ya da bir gerçeklikten yoksun gerçeğin modeller aracılığıyla türetilmesine hipergerçek yani simülasyon denilmektedir" (Baudrillard, 2003a, s. 15-16). Baudrillard'a göre, gerçeğin ortadan kalkması ile birlikte gerçek ile taklidin birbirinden ayırt edilemediği, aslında simülasyonun gerçekle karıştırıldığı bir uzam oluşmuştur: "Simülasyon uzamı gerçekle modelin birbirine karıştıkları bir uzamdır. Gerçekle rasyonel arasında artık ne eleştirel ne de spekülatif bir uzaklık vardır" (Baudrillard, 2003b, s. 70). 
Baudrillard'ın gerçeğin yerini aldığını iddia ettiği simülakrlar, "bütün dünyayı egemenliği altına alarak tüm olayları 'anlamsızlaştırmakta', anlamı kısa süreli 'geçici' senaryolara, yaşamıysa bir hayatta kalma mücadelesine hatta önemsiz bir iddia, bir bahse dönüştürmektedir" (Baudrillard, 2003a, s. 63-64). Baudrillard'a göre, simülasyon evreninde gerçeklikle ilintili olan evrensel proje ve arzuları yok etmenin yolu, caydırmadır. Caydırma, bir strateji olmadığı gibi, öznesi ya da rakibi yoktur. Bunun yerine caydırma, nötralize olmuş bir şiddettir. Bu şiddet fiziksel değildir, soyut ve kendinde bir potansiyeldir. Amacı, toplumsal çatışma ihtimalini devre dışı bırakmaktır. Şiddet, tüm karşıtlıklar, hedefler ve çatışmaların donmasına neden olmaktadır (Baudrillard, 2003a). Böylece, Baudrillard modern topluma özgü karşıtlık ve çelişkilerin artık var olmayacağı iddiasında bulunmaktadır.

Karşıtlıkların son bulması, Baudrillard'a göre çağdaş dünyada insanların yaşamlarına ilişkin anlamı yitirmeleriyle ilgilidir: "Anlam artık toplumlarımızı sürükleyip götüren ideal çizgi olmaktan çıkmıştır" (Baudrillard, 2003b, s. 18). Baudrillard'a göre, toplumsallik 1929 talep krizinin ürünüdür. İktidar bu tarihten itibaren politik, ideolojik, kültürel ve seksüel anlam üreterek endüstri ürünlerine ilişkin talebi canlandırmaya çalışmıştır. Bu eksende, anlam üretiminin yoğunluğu nedeniyle gerçekleşen anlam patlaması, anlama zarar vermiş ve sonuçta anlamın ortadan kalkmasına neden olmuştur (Baudrillard, 2003b). Baudrillard'in analizinde, bugünün insanı yolunu kaybetmiş, üstüne üstlük haritalara ihtiyaç duymayan bir insandır: "Toplumsal hedef ve amaçlardan yoksun, ancak buna karşın, bireysel hedef ve amaçların kendisini hiçbir yere götürmeyeceğini bildiği bir evrene ait bir insan" (Adanır, 2004, s. 23).

Anlam yoksa, yabancılaşma da yoktur. Baudrillard'ın hipergerçeklik evreninde bireylerin kendisine yabancılaşacağı anlamlı bir gerçeklikten söz edilemeyeceği gibi, bazı gerçeklerin üstünü örtecek illüzyonların varlığı da söz konusu olamaz. İllüzyonlar, ancak gerçeklikten söz edilebilirse var olabilir. Bireyler, sınıflar ya da toplumlar arası kutuplaşmaların son bulması anlam dolanımını olanaksız kılmakta, böylece geriye yabancılaşılacak bir şey kalmamaktadır. Bu bağlamda, Baudrillard kitlelerin güdümlenemeyeceğini öne sürer. Baudrillard'a göre iktidar, varlığını sürdürebilmek için kitleleri aldattığını sanmakta, bu düşünce sayesinde iktidar olduğuna inanabilmektedir. 
Oysa iktidarın ne yaptığı ve neyi amaçladığı kitlelerin umurunda bile değildir (Baudrillard, 2003b).

Baudrillard'a göre, zaten iktidar politik boyutundan bütünüyle arındırılmış, kitlesel olarak tüketilebilen bir mala dönüşmüştür. Baudrillard, politikada sol ve sağ arasındaki ayırımların belirsizleştiğini iddia eder. Sol ve sağ birbirlerinin görevlerini yerine getirmektedir. Her iki kutbun da kendilerine ait projeleri kalmamıştır (Baudrillard, 2003a). Modern devrimler ile birlikte yükselişe geçen politika Baudrillard'a göre, bugün temsil etme işlevini yitirmiş, bir oyuna dönüşmüştür. Bugün, politik olana karş1lık gelen sınıf, halk gibi organizasyonlar ortadan kalkmış durumdadır. Onların yerine, asla politik bir gönderen olamayacak sessiz bir çoğunluk her yeri kaplamıştır (Baudrillard, 2003b).

Bu noktada Baudrillard'ın çarpıcı bir iddiası ile karşılaşırız:

Bütün bunlar toplumsalın sonunu işaretlemektedir. Toplumsalın enerjisi azalmakta, özgünlüğü elden gitmekte, tarihsel niteliği ve idealliği buharlaşıp uçmaktadır. Toplumsal, bir sistem uğruna adını yitirirken, politika da yok olmaktadır. Toplumsal artık anonimleşmiştir. O artık kitledir. Kitlelerdir (Baudrillard, 2003b, s. 24).

Toplumun sona erdiği iddiası Baudrillard'ı postmodernizme götüren temel saiki oluşturmaktadır. Günümüzde artık gerçek bir evrende yaşamıyor olduğumuz düşüncesi, “birlikte yaşam”ın motivasyon kaynağı olan "toplumsal" anlamın ortadan kalkışına işaret etmektedir. Toplumun sonu bir toplumsal formasyona ilişkin anlamın yitimi karşısında yeni bir anlam düzeninin ortaya çıkmamasının bir sonucu olarak gerçeklik kazanmaktadır. Weber'in analizlerinde görülen, gelenekten modernliğe geçişi sağlayan rasyonelleşme sürecinin anlam yitimine yol açtığı iddiası modernliğin kendine özgü bir anlam düzeni yaratması ile paralel olarak gelişmiştir6́. Buna karşıllk, Baudrillard'ın analizlerinde modernliğe özgü anlamların kitlelerde bıraktığ 1 etkinin sona ermiş olması yeni bir anlamlar düzeneğinin ortaya çıkışı ile sonuçlanmamakta, dolayısıyla toplumsalın kendini var ettiği temelin ortadan kalkmasi toplumun sonunu getirmektedir.

Baudrillard'a göre, toplumsalı, kitle iletişim araçları üretmekte ve aynı zamanda yok etmektedir. Kitle iletişim araçları, "görünüşte daha çok

\footnotetext{
${ }^{6}$ Weber'in büyü bozumu olarak ifade ettiği anlam yitimi sürecine ilişkin olarak bkz. Weber, 2012.
} 
toplumsal üretirken, toplumsal ilişkilerle toplumsalın kendisini derinlemesine nötralize etmektedirler" (Baudrillard, 2003b, s. 56). Baudrillard'a göre, bu durumun nedenlerinden biri, kitle iletişim araçlarının iletişim kurmak ya da anlam üretmek yerine iletişim oyunu oynuyor olmasıdır. Diğer bir neden ise, iletişim araçlarının kitleleri mesaj bombardımanına tutarak toplumsal yapıyı bozmalarıdır. Böylece anlama ait tüm içerikler, egemen iletişim araçları tarafindan yutulmaktadır. Olaylar bir sonuca neden olmamakta, sadece peş peşe sıralanmaktadır. Olaylar ve gündem daha bir sonuca ulaşamadan sürekli değişmekte, böylece anlamlarını daha ortaya çıktıkları anda yitirmektedir. Dolayısıyla, olaylar bir görüntü olmanın ötesine geçemedikleri için, kitlelerde bıraktığı etkiler anlamsızlaşmaktadır (Baudrillard, 2003a).

Baudrillard'a göre, sistem kitle iletişim araçlarını bireyi düzenin içine dahil etmek amacıyla kullanırken, istemediği sonuçlarla karşılaşmaktadır. Gerçeği, görüntü ve sözlere dönüştürerek ortadan kaldıran sistem, kitleleri görüntü, ses ve yazılardan oluşan mesaj bombardımanlarına tutarak, kitleleri kendisinin sağlıklı, güvenilir ve başarılı bir sistem olduğuna ikna etmeye çalışmaktadır. Buna karşılık, üzerinden görünümlerin akıp geçtiği saydam bir yüzeyden başka bir şey olmayan ekran, anlamı ve içerikleri nötralize etmekten başka bir işe yaramamaktadır (Adanır, 2004). Anlamı yok eden "kitle" iletişim araçları, adına uygun bir biçimde, toplumun kitleye dönüşümü işlevini yerine getirmiş olmaktadır. Böylece, toplumsalın sona ermesiyle geriye kalan "artık" olarak tanımlanabilecek bir kitle ortaya çıkmaktadır. Bu kitle herhangi bir hak iddiasında bulunma yeteneğini kaybetmiş, uyuşmuş, tepkisizleşmiş, sessiz bir yığını ifade etmektedir.

Baudrillard'a göre, kitleler kendilerine gönderilen bütün mesajlara karş1 duyarsızdırlar. Sistemin akılcı iletişim zorlamalarına karşı koymakta; anlam yerine gösteri istemektedirler. Kendilerine gönderilen her şeyi gösteriye dönüştürmektedirler. Kitleler, artık temsil edilememekte, yalnızca sondajlar, testler ve referandum aracılığıyla sik sik yoklanmaktadırlar (Baudrillard, 2003b). Böylece Lyotard'da görüldüğü gibi Baudrillard da sosyal teorinin sonunu ilan eder: "Toplumsal artık nesnel bir şekilde açıklanamaz" (Baudrillard, 2003b, s. 34). Baudrillard'a göre, artık, teorinin temsil işlevini, sondajlar ve istatistik görmektedir. Ancak bu, gerçek bir temsil değildir. Bir kitle hayali üzerinden, önceden bilinen yanitlar üretmektedirler. Çünkü 
Baudrillard'a göre, toplumla birlikte özne de ortadan kalktığı gibi, onların yerini alan kitlelerin de düşünceleri, amaçları ve üretebilecekleri tarihleri yoktur (Baudrillard, 2003b).

Toplumun sessiz çoğunluk anlamına gelen kitleye dönüşmesi, Baudrillard tarafindan medyanın ve iletişim teknolojisinin gelişimiyle açıklanır. Bu bağlamda, kitlenin rolü yalnızca seyirci olmaktan ibarettir: "Kitleyi, kitle iletişim araçlarının dışında bir yerde aramak boşunadır" (Baudrillard, 2003b, s. 33). Böylece Baudrillard, teknolojik determinizme yakalanmış bulunmaktadır. Ancak Baudrillard'ın belirleyici olarak ele aldığı kurum olan teknoloji, yalnızca, bilgi akışıyla ilgili olan iletişim teknolojisidir. Dolayısıyla Baudrillard, materyalizmle bağlarını kopararak, toplumsal değişimlerin nedenlerini üstyapısal kültür alanında aramaktadır:

Uzun bir süreden bu yana kültür, sanat, politika hatta cinsellik alanlarında (üstyapısal denilen alanlarda) işlemselleşmiş bulunan bu süreç günümüzde 'altyapısal' denilen alanın tamamını etkilemektedir. Aynı belirsizlik orayı da egemenliği altına almıştır. Ekonominin belirleyiciliğini yitirmesiyle birlikte, kendisini belirleyici bir süreç olarak algılama olanağı da hiç kuşkusuz ortadan kalkmaktadır (Baudrillard, 2002, s. 7).

Baudrillard'ın ekonomi politikten uzaklaşması, üretimin sona erdiği iddiasına dayalıdır. Baudrillard'a göre, içinde bulunduğumuz çağda üretimin içeriklerine kadar her türlü erekliliği sona ermiştir. Günümüzde kapitalist düzenin yerini hiperkapitalist bir düzen almıştır. Bu değişim emek gücünün ürettiği artı-değer üzerine kurulu ticari değer yasasından emeğin artık bir güç olmaktan çıkarak bir göstergeye dönüştüğü yapısal değer yasasına geçişi ifade etmektedir. Art1-değerin sona erdiği bu koşullarda emek artık bir güçten çok, sıradan bir göstergeye, kapitalist sistemin yapı taşı olan fabrikalar da toplumun tamamını kapsayan bir şeye dönüşmüştür. Böylece emek, artık her yerde bulunmakta, tarihsel bir praksis olma özelliğini kaybetmektedir (Baudrillard, 2002).

Toplumsal değişimin itici gücü olarak medyayı merkeze almasının Baudrillard'ın bakış açısındaki paradigmal değişimle ilişkili olduğu açıktır. Materyalizmden koparak üstyapısal analize yönelmesi Baudrillard'ı tarihin motoru olarak sınıf çatışması ilkesinin reddine götürmektedir. Bununla birlikte, Baudrillard sınıfların ve sınıflar arasındaki çelişkinin ortadan kalkmasını sınıflar arası eşitsizliklerin giderilmesinden ziyade üretimin sonu 
iddiasına dayandırmaktadır. Burada Baudrillard'ın liberal yaklaşımdan farklı bir perspektife sahip olduğu görülmektedir. Sınıf çatışmasının sona erdiği iddiası aynı süreçte liberal yaklaşımda da ortaya çıkmıştır. Ancak, bu iddia Soğuk Savaş'in sonunu getiren bir gelişme olarak, liberal demokrasinin sosyalizme karşı evrensel zaferini ilan etmesi çerçevesinde temellendirilmektedir. Bu gelişme aynı zamanda tarihin sonunun geldiğini ortaya koymaktadır ${ }^{7}$.

Nitekim, sınıf çatışmalarının ortadan kalktığı düşüncesinin sonucu olarak, Baudrillard'ın da tarihin sonunu ilan etmesi kaçınılmazdır: "Yaşamın can sıkıcılığı, günlük yaşam, eskiden küçük burjuva olarak kınanan (...) apolitik olan her şeyin ön plana çıkması, tarih ve politikayı soyut bir olaylar bütünü olmaya doğru itmektedir" (Baudrillard, 2003b, s. 38-39). Bu doğrultuda Baudrillard, tarihin günümüzde geçmişe gönderme yapan bir senaryo olduğunu düşünür. Tarih, sinema aracıllğıyla bugüne taşınmaya çalış1lırken, bu durum bilinçlenmeyle değil, yitirilmiş bir gönderenler sistemine özlemle ilişkilidir. Gerçek yaşamda da sinemadakine benzer bir tarih yaşanmış olmasına karşın, bugün tarihin anımsatılması, aslında tarihsel gerçekliğin ortadan kalktığını kanıtlamaktadır. Böylece sinema, tarihin ortadan kaybolmasına katkıda bulunurken, tarihi fetişleştirmektedir (Baudrillard, 2003a).

Baudrillard, bütün bunların sonucu olarak toplumsal durumun bugün ulaşmış olduğu noktayı nihilizmin egemenliği olarak anlar. Baudrillard'a göre, modernliğin tarihinde ilk önemli nihilist çıkış, Aydınlanma akılcılığının estetik bir eleştirisi olan Romantizm akımıdır. Sürrealizm, Dadaizm, absürd anlayışı ve politik nihilizm, anlam düzeninin yıkıldığı dönemde ortaya çıkan politik eleştiriler olarak, ikinci önemli nihilist çıkıştır. Bugünün nihilizminin ise bunlarla ilişkisi yoktur. Bugünün nihilizmi, tıkanma noktasına gelmiş bir dünyada hüküm süren, eleştirellikten uzak ve tepkisizlikten başka bir anlama gelmeyen saydam bir nihilizmdir (Baudrillard, 2003a).

Baudrillard bir nihilisttir ve kendi nihilist eğilimlerini toplumdaki egemen bakış açısı gibi göstermektedir. Bu nihilizm, sosyolojik gerçeklere dayanmak yerine asıl olarak felsefi bir yaklaşımın sonucudur. "Baudrillard'ın

\footnotetext{
${ }^{7}$ Bu konuda bkz. Fukuyama, 1999.
} 
çözümlemesi anlık deneyimin altındaki her gerçekliği inkar etmesi ve dolayısıyla bu esası özün taraftarı olan şeylere ait yüzeylerin değerini düşüren yorumsamanın 'derin modeli'ni reddetmesiyle, temelde Nietzschecidir' (Callinicos, 2001, s. 225). Ancak Baudrillard'ın nihilizmi, var olduğunu varsaydığı toplumsal bataklıktan kurtulmak için, Nietzsche gibi bir çözüm önerisi sunmamaktadır: "Baudrillard'ın nihilizmi sevinçten, enerjiden, daha iyi bir geleceğe duyulan umuttan yoksundur" (Kellner, 2000, s. 377). Baudrillard'ın Batı toplumunun örgütleyici ilkelerinin içe doğru patlamayla yıkıldığı iddiası ile ulaştığı yer, umutsuz bir postmodernizmdir:

XX. yüzyıl ya da post-modernleşme tarafından gerçekleştirilen ve bir önceki yüzyılda görünümlerin yok edilmesine eşdeğerli muazzam anlam kıyımı sürecini ikinci bir devrim olarak kabul ediyor, varlığını onaylıyor, sorumluluğunu üzerime alıyor ve çözümlüyorum (Baudrillard, 2003a, s. 227).

Baudrillard'ın postmodernliğe ulaşmış hipergerçeklik evreni, Batı merkezli bir analizin sonucudur. Ele aldığı toplum, ekonomik ve kültürel anlamda doyuma ulaşmış bir toplumdur. Bu analize göre, "koymuş oldukları hedef ve amaçları çoktan aşıp geçmiş ve bu arada illüzyonlarını yitirmiş olan Batılı toplumlar, bundan böyle hangi yöne doğru ilerleyeceklerini bilemez hale geldiklerinden (...) kendi etraflarında dönmeye başlayarak bir kısır döngü içine girmiş bulunmaktadırlar" (Adanır, 2004, s. 19). Oysa Baudrillard'ın bittiğini varsaydığı toplumsallığa özgü olgu, kurum ve yapılar hala ileri kapitalist ülkeler başta olmak üzere dünyanın her bölgesinde toplumsal yaşamın dinamikleri olmayı sürdürmekte ve değişimlere öncülük eden teknoloji de üretimin bitişinin değil, gelişiminin bir sonucu olarak kendisini göstermektedir.

Yeniden üretim olgularının (moda, medya, reklam, bilgi ve iletişim ağları) çoğalması, maddi üretimin devasa boyutta genişlemesini gerektirir; imgelerin daha büyük oranda dolaşımı, çok çeşitli fiziksel ürüne -televizyon, video-kaydedici, uydu anteni vb.- bağlıdır. Daha temel olarak, insanlar yalnız MTV ile yaşamıorlar; üretimin organizasyonu ile denetlenmesini hala toplumların doğasının önemli belirleyicileri kılan yemek, giyim ve barınma gibi dünyevi gereksinimlere sahip olmayı sürdürüyorlar (Callinicos, 2001, s. 228).

Böylece, modernlikten postmodernliğe geçişin nasıl gerçekleştiği sorusu, Baudrillard' da da yanıtlanamamıştır. Baudrillard, söz ettiği kırılmanın 
nedenlerini açıklamak yerine, bizi anlamsız bir dünya imgesinin uçurumuna sürüklemektedir. "Teorisi iyi bir bilim-kurgu sayılabilir, ama zayıf bir toplumsal teoridir. Yeterli bir bağlamlaştırmadan yoksun olan teorisi soyut, tek yanlı (...) ve şimdiki çağın çok sayıda kasvetli gerçekliklerini ve sorunlarını görmekten aciz olma eğilimindedir" (Kellner, 2000, s. 378).

Baudrillard'ın postmodern yaklaşımının temel sorunu Lyotard'da görüldüğü gibi, tek yönlü bir bakış açısına sahip olmasıdır. İletişim teknolojisinin işleyişinin toplumun yerine kitleleri ikame ettiği düşüncesinin temellendirilmesinin güçlüğünün yanında, bu yaklaşım modernliğin sona ererek postmodern bir çağın başladığına kanıt olmakta yetersiz kalmaktadır. Yeni bir çağın başladığının ileri sürülebilmesi için ekonomik, siyasal ve kültürel sahalarda yapısal dönüşümlerin varlığını analitik olarak ortaya koymak gereklidir. Ancak, Baudrillard'ın sahip olduğu teknolojik determinist anlayış bütünsel bir teorik çerçeve içinde farklı sahaların tikel analizlerini mümkün kılmamaktadır. Bununla birlikte, Baudrillard'ın analizleri arasında medyaya ilişkin olanları önemsenebilir. Ancak bunlar da anlam üreten medyaya karşı eğlence talep eden bir kitle çerçevesiyle anlaşılmak yerine, medyanın kapitalist sistemin çıkarları adına anlamı ve değerleri manipüle ettiği, dolayısıyla toplumun iletişim kurma kanallarını bozduğu yönünde bir kavrayış içinde, tersine çevrilerek okunmalıdır ${ }^{8}$.

\subsection{Fredric Jameson: Geç Kapitalizmin Kültürel Mantığı Olarak Postmodernizm}

Yaşadığımız çağı postmodern olarak nitelendiren kuramcılar arasında en güçlü argümanları öne süren yazar, Jameson'dır. Jameson, Marksist olması bakımından postmodernizmin önde gelen diğer düşünürleri olan Lyotard ve Baudrillard'dan ayrılır. Jameson, Marksist perspektife bağlı bir analiz içinde günümüz dünyasını kapitalizmle ilişki içinde değerlendirerek, çağımızı kapitalist içeriğin sahip olduğu yeni biçim şeklinde "postmodern" olarak niteler. Dolayısıyla Jameson, postmodernizmi kapitalizmin yeni bir evresinin kültürel ifadesi olarak ele alır.

\footnotetext{
${ }^{8}$ Bu konuda Habermas'ın (2001) "Para ve gücün dilsiz medyası" çözümlemesi yol gösterici olabilir.

${ }^{9}$ Postmodernliği onayladıkları dönemde artık Marksizm ile ilişkilerini kesmiş olmalarına rağmen, yine de Lyotard ve Baudrillard'ın geçmişlerinde Marksist oldukları belirtilmelidir.
} 
Jameson'ın analizi, diğer postmodernistlerin yapmayı reddettiklerinin aksine tarihsel bir dönemselleştirme üzerine kuruludur:

Geçmişi böyle ele alma metodunun sonuçta bilgiyi kayıt ve depolamanın bir biçimi olarak kroniğe geri dönüş olacağını söylemek çok basit olur: Tarihsel gerçekliğin kendisi muhtemelen modern bir icat olduğu sürece, modernin eleştirisi ve reddi, en azından bu ya da şu modern öncesine gerileme seçeneğini yaratmaya hükümlüdür. (...) ya da başka bir deyişle, (...) dönemleștirmeden yapamayız (Jameson, 2004, s. 32).

Jameson'ın dönemselleştirmesinde kapitalizmin geçirdiği aşamalar kültürel boyutlarıyla birlikte ele alınır. Kapitalizmin ilk aşaması, Marx'ın çözümlediği piyasa kapitalizmidir. İkinci aşama, teoride Lenin tarafından ortaya konulan tekelci kapitalizm ya da klasik emperyalizm dönemidir. Jameson, Ernest Mandel'in incelemesinden ${ }^{10}$ hareketle, bugün, kapitalizmin geç üçüncü aşaması olan çokuluslu kapitalizm dönemine ulaştığımızı bildirir (Jameson, 2005).

Geç kapitalizmde sermaye, artık fabrikalarda, diğer branşlarla rekabet eden endüstri ve üretken bir teknoloji olarak değil, daha yoğun karlılığa sahip borsalarda spekülasyon zemininde varlı̆̆ını sürdürmektedir. Sermaye, artık mali sermaye momentidir. Jameson'a göre, sermayenin bu hızlı dolaşım koşullarında kültür de yeni bir biçime bürünmüştür. Kapitalizmin ilk evresinde kültürel alanı realizm, ikinci evresinde modernizm temsil ederken, geç kapitalizmin kültürel biçimine ise postmodernizm karşllık gelmektedir (Jameson, 2005).

Jameson'a göre, postmodernizm geç kapitalizmin kültürel mantığıdır. Postmodernizm yeni bir küresel askeri ve ekonomik Amerikan egemenliği akımının içsel ve üstyapısal ifadesidir. Bu bağlamda postmodern, bugün çok farklı kültürel dürtülerin, içinde kendilerine yer edinmek zorunda oldukları bir güç alanını oluşturmaktadır. Kapitalizmin önceki dönemlerinde kültürel alanın ekonomiden yarı-özerkliği, geç kapitalizm ile birlikte tahrip edilmektedir. Kültürün görece özerkliğinin kaybolması, tamamen ortadan kalkması değil, patlama yapması anlamındadır. Jameson'a göre, geç kapitalist dönemde kültür, toplumsal alanın her yanına yayılmıştır ve ekonomiden devlet iktidarına, sosyal pratikten ruhun yapısına kadar her şeyin kültürel olduğunu söyleyebiliriz (Jameson, 1990). Bu noktada Jameson'da Baudrillard

${ }^{10}$ Bkz. Mandel, 2008. 
etkisi göze çarpmaktadır. Toplumsal hayattaki her şeyin kültürel hale gelmesi Baudrillard'ın analizlerindeki gibi, toplumsal yaşamın her alanının göstergeler ve iletilerle dolup taşması ile ilgilidir. Böylece, tüketim kültürünün imajları, arzuları ve estetik boyutlarının egemenlik kurmuş olması tüketim toplumunun kültürel bir toplum haline gelmesini ifade eder (Featherstone, 2005). Bununla birlikte, Jameson kültürün patlama yapmasının nedenlerini, kapitalizmin geç dönemindeki işleyiş biçiminde bulmaktadır. "1960'1ı yılların başlarından itibaren, kültür üretiminin genel olarak meta üretimi ile bütünleştiği bir çağa girdiğimizi ileri sürer” (Harvey, 2010: 80). Dolayısıyla, bu çağda kültürün merkezileşmesindeki temel itki kültürün kendisinden ziyade kapitalizmin büründüğü yeni biçimdir.

Reklamcılık ve yayıncılıktan ürünlere ve binalara, sanatsal metalardan çok satan filmlere kadar geç kapitalizme bağlaşık olan yeni ticari kültürel biçimler, Jameson'a göre, klasik kapitalizmin eski folk ve gerçekten popüler olan kültür türlerinden ayrı değerlendirilmelidir. Bu noktada kabul edilmesi gereken şey, yüksek kültür (burjuva kültürü) ile popüler kültür (kitle kültürü) arasındaki ayırımların ortadan kalkmış olduğudur. $\mathrm{Bu}$ görünümler en iyi şekilde sanatta izlenebilir. Tekelci kapitalizm döneminde marjinal ve muhalif olan modernist sanat, ortak beğeniye ve mevcut gerçekliğe meydan okuyan, yerleşik düzen için daima yıkıcı olabilen bir sanattı. Oysa günümüzün sanatı, marjinallikten merkeziliğe doğru kaymış durumdadır. Bu durum, döneminin muhalif sanatçı ya da yazarlarının bugün klasik ve gerçekçi hale gelmelerinde, ileri modernizmin ürünlerinin tüm toplum tarafindan kabul edilip ticari başarıyı yakalamış olmalarında ve ileri modernist estetiğin sokaklardan akademiye taşınarak kabul görmesinde gözlemlenebilir (Jameson, 2005). Jameson'a göre, sanatın postmodern görünümleri yaratıcı devrimci sanatın akademik resmiyete ve kültürel sahanın merkezine çekilmesiyle ifade edilir.

Jameson'a göre, günümüz sanatının uygulamalarının temelini "pastiş"11 oluşturur. Pastiş, eşsiz ve kişisel anlamda üslubun sonunu işaretler. Bugün sanatsal yenilikler ortadan kalkmış durumdadır. Artık sanat, ileri modernist eserlerin taklidi ve çeşitli parçaların birbirine eklemlenmesiyle (eklektizm) oluşturulmaktadır. Üslup ideolojisinin ortadan kalkmasıyla birlikte kültür

\footnotetext{
${ }^{11}$ Pastiş: Mevcut sanat eserlerini taklit etme yoluyla ortaya çıkarılan sanat eseri.
} 
üretenlerin başvurabilecekleri tek yer, “geçmiş”tir (Jameson, 1990). Özgün kültürel üretimin yerini eklektizmin alması, Jameson için yaratıcılığın sonu anlamına gelir: "Biçemsel yeniliğin artık olanaklı olmadığı bir dünyada geriye sadece ölü biçemlere öykünmek, maskelerle ve düşsel müzelerdeki biçemlerin sesleriyle konuşmak kalmaktadır” (Jameson, 2005, s. 18).

Çağdaş sanatın sahip olduğu pastiş, kolaj, cover gibi uygulamalar, otantikliğin aksine taklitle karakterize olmasına rağmen, toplumda anlaşılmaz bir coşkuyla karşılanmaktadır. Jameson'a göre, bu durum kapitalizmin belirsizleşmesinin bir yansımasıdır. "Postmodern sanatın neden olduğu tuhaf coşku, 'histerik yüce'nin, küresel ekonomik sistemin işleyişinin artık temsil edilemediğinin ya da zihinde canlandırılamadığının farkedilmesine tepki olarak gösterdiğimiz heyecan ve dehşetin bir örneğidir" (Callinicos, 2001, s. 199).

Pastiş uygulamasının evrenselleşmesi, Jameson'a göre öznenin ölümüyle ilgilidir. Normun gölgelendiği, dilin çeşitli kişisel konuşma tarzlarından biri olan nötr ve şeyleşmiş medya konuşmasına indirgendiği bir ortamda, sosyal yaşam linguistik olarak parçalanmaktadır. Klasik kapitalizmde egemen sınıfın düşüncelerinin burjuva toplumunun baskın ideolojisini oluşturması söz konusuyken, bugün ileri kapitalist ülkeler normsuz, üslupsuz ve uçarı bir heterojenliğin alanı durumundadırlar (Jameson, 1990). "Kapitalizm kendi içsel mantığının bir işlevi olarak farklılıklar ya da farklılaşma (...) üretmektedir" (Jameson, 2005, s. 54). Bu koşullarda gündeme oturan mikropolitika problemiyle birlikte, özne geçmişiyle geleceğini tutarlı bir yaşantı halinde örgütleme gücünü kaybetmiştir. Böyle bir öznenin kültürel üretimlerinin parça yığınlarından ve rastgele heterojenin, şans eserinin pratiğinden başka bir sonuç vermesi mümkün olamamaktadır (Jameson, 1990).

Bu bağlamda, Jameson'a göre, postmodern dönemin özelliklerinden biri, ilerleme hedefinin son bulmuş olmasıdır. Bu durum, postmodernizmin mantıksal çatışkısında mevcuttur. Jameson'a göre, postmodernizmin paradoksu, toplumsal yaşamın her alanındaki hızlı değişim ile metalar, duygular, uzam ve dil gibi değişim unsurlarının standartlaşması arasındaki eşdeğerliktir. Toplumsal fenomenler en yüksek derecede değişir gibi görünürken, aynı zamanda standardize edilmektedir. “Aynı”nın mutlak fark 
aracılığıyla varlığını sürdürmesinin bilincimizde bıraktığı iz, ütopyacı imgelemin kendisine olan güvenin sarsılmasıdır (Jameson, 2005). Dolayısıyla, postmodernitede her şey değişime uğrarken, artık hiçbir şey değişmemektedir. Bunun anlamı, değişimin devrimci değil, rutin olduğudur. Değişimin sıradan hale gelmesinin sonucu olarak da ilerleme düşüncesi insan imgeleminde bir ideal olmaktan çıkmakta ve gittikçe yaşamın amacı olmaktan uzaklaşmaktadır.

Jameson'a göre, postmodernite İkinci Dünya Savaşı sonrası başlamış, 1960'larda belirgin bir görünüm kazanmıştır: "Son y1llarda, bir zamanlar moderniteler olarak tanımlanan kopuşlar, postmodernite olarak tanımlanmaya başland. Bu yüzden 1960'lar bir şekilde daha ileri bir modernite demenin gereksiz görüldüğü her türden önemli değişiklikler getirdi” (Jameson, 2004, s. 34). Jameson, postmodernizmi reddetmek ya da sevinçle karşılamak yerine, postmodernliğin yok sayılamaz bir gerçeklik olduğunu düşünür: “Asıl mesele, postmodernizmin kolayca reddedilmesinin, onun olumlu yönlerinin rahatlıkla övülmesiyle eşdeğer ölçüde olanaksız olduğu bir postmodern kültür içinde yaşıyor olmamızdır" (Jameson, 2005, s. 40).

Jameson, kapitalizmin yeni egemenlik biçimi karşısında diyalektik kavrayıştan uzaklaşmamak adına, postmodern olduğunu iddia ettiği kültürün içinde sosyalist dönüşümlerin filizlenebileceğini öngörür. Nasıl ki Marx ve Lenin kapitalizmin ulaştığı boyutları sosyalizme erişmenin koşulu olarak gördülerse, Jameson da yeni dünya sisteminin radikal bir evrensel dönüşümün yaratılmasını sağlayacak potansiyeli içinde barındırdığını düşünür (Jameson, 1990).

Jameson, postmodernizmi sosyalist bir tarihsel evreye geçiş için gerekli görse de onun postmodernizmi temelden hatalı bir temsil üzerine kuruludur.

Jameson modernizmin tükenmiş biçimlerine nostaljik olarak yapışıp kalmaktansa, postmodernizmin özündeki eleştirel potansiyeli keşfediyor olmamız gerektiğini savunur. Aslında kendisi, yeni biçimlerin yıkıcı olasılıklarını gösterme konusunda biraz cimri davranır ancak, esas güçlüğün yattığı nokta bu değildir. Asıl güçlük metodolojiktir (Callinicos, 2001, s. 201).

Marksist olmasından ötürü, Jameson, yeni kültürü kapitalizmin çağdaş biçimine bağlı kılsa da, kültürün bir ifadesi olarak kavradığı postmodernliği yeni bir tarihsel çağ olarak özgünleştirir. Ancak, bir insanlık durumu tek başına kültürel sahadan hareketle çıkarsanamaz. Eğer tarihsel çağlar üstyapı 
ile anlaşılsaydı, Jameson için kapitalizmin önceki aşamalarına denk düşen kültürel mantıklar olan realizm ve modernizmin modernliğin yerine geçmeleri ve kapitalizmi de kendi ekonomik sistemleri olarak içermeleri gerekirdi. Dolayısıyla, bu yaklaşım Marksist yöntemle çelişmektedir. Jameson'ın analizi dönemimize ilişkin kültürel eğilimleri yakalamış olmasına rağmen, postmodernliği yeni bir çağ olarak sunmakta yetersiz kalmaktadır.

Jameson'ın teorisi Lyotard ve Baudrillard'in postmodern yaklaşımlarından ayrışmaktadır. $\mathrm{Bu}$ ayrışmanın en önemli göstergesi Jameson'ın hareket noktasının bu iki teorisyendeki gibi modernlik karşıtlığı olmamasıdır: "Fredric Jameson'ın postmodernizm üzerine yazıları, Baudrillard ve Lyotard gibi yapısalcılık sonrası ve postmodernist teorisyenler tarafından radikal toplumsal teorinin karşısına çıkartılan meydan okumaları karşılama girişimi olarak okunabilir. $\mathrm{Bu}$ girişiminde Jameson hem bu teorisyenlerin içgörülerini ve katkılarını temellük etmekte hem de alternatif bir postmodern toplumsal teori sunmaktadır" (Kellner, 2000: 390). Ancak Jameson'1n postmodern teoriyi kapitalizm ve kültür kıskacına sıkıştırması yaşadığımız evrenin bir postmodern çağ mı yoksa "kültürel” bir kapitalizm mi olduğunu belirlemede net bir yaklaşım sahibi olmadığını ortaya koymaktadır.

\section{SONUÇ}

Postmodernizm 1970'li yıllarda dünya konjonktüründe görülmeye başlayan değişimlerin sonucu olarak ortaya çıkmış bir teoridir. Tarihin belli bir dönemindeki değişimleri genel olarak insanlık tarihiyle ilişkilendiren postmodernizm, böylece, tarihte bir kırılma gerçekleştiğini öne sürmektedir. Bu kırılmanın teorik anlatımını yaptığı iddiası kısa sürede karşılık bulmuş ve postmodernizmin sosyal bilimlerde moda haline gelmesini sağlamıştır.

$\mathrm{Bu}$ çalışmada postmodern teorinin kurucu düşünürleri olan Lyotard, Baudrillard ve Jameson'ın yaklaşımları eleştirel bir değerlendirmeye tabi tutulmuştur. Ele alınan düşünürlerin ortak noktası, modernliğin sona erdiğini ve insanlık için yeni bir çağ olan postmodernitenin ortaya çıktı̆̆ını düşünmeleridir. $\mathrm{Bu}$ düşünürlere göre, Aydınlanma döneminde hazırlanarak politik ve ekonomik devrimlerle hayata geçen modernliğin kurumları ortadan kalkmıştır. Lyotard, bu iddiayı modern bilgi yapısının üzerindeki uzlaşmanın son bulduğu varsayımıyla temellendirmeye çalışırken, Baudrillard, ortaya 
çıkan yeni durumun artık bir toplumsallık içermediğini ve buna bağlı olarak modern bir kolektif organizasyondan söz edilemeyeceğini savunur. Jameson ise kapitalizmin yeni bir evresinin ortaya çıkardığı yeni kültürel yapının modernlikten koptuğunu ileri sürerek, postmodern dönemi ilan eder.

Esas ilginç olan şudur ki, her üç teorisyen de aynı döneme odaklanarak, birbirlerinden farklı üç sonuca ulaşmaktadır. Lyotard, postmodern durumu farklılı̆̆ın ifade edilebildiği bir "altın çă̆" gibi kutsarken, Baudrillard, aynı döneme bir "imaj” devri olarak bakmakta ve olumlu bir toplumsal değişime olan inançsızlığıyla nihilizme işaret etmektedir. Öte yandan, aynı post-modern durumda gelecek için “umutlar” gören Jameson için, günümüz, sosyalizme düne göre daha çok göz kırpmaktadır.

Postmodern teori tarihsel değişimi öznenin gündelik yaşamda yeni eylem biçimleri geliştirmesine bağlı kılmaktadır. Özellikle teknolojinin gelişimi öznenin eylemlerinde belirleyici olarak değerlendirilmektedir. $\mathrm{Bu}$ bağlamda, endüstri toplumundan bilgi toplumuna geçildiği iddiası postmodern kırılmanın temeli olarak kabul edilmektedir. Bu yaklaşıma göre, yeni bilgi teknolojileri aracılığıyla bilgiye ulaşmanın kolaylaşması ve bilginin kitleselleşmesi uzmanların bilgi üzerindeki tekelini kırmıştır. Geçmişte uzmanlar eliyle enforme edilen bireylerin yolunu kaybetmesi ve kendilerini bir boşlukta bulması kitlelerin anlam dünyasını sarsmıştır. Bunun sonucunda, ilerleme ideali ortadan kalkmış, geleceğe yönelme yeteneğini kaybetmiş olan öznenin kendisini geçmiş üzerinden kurması dışında bir seçeneği kalmamıştır. Kendilerini bir toplum halinde örgütleyecek ortakl1kları kalmayan bireylerin dünyasında farklılıklar ön plana çıkmaya başlamaktadır. Farklılıkların serbest kalması ve bireyin geçmişe yönelmesinin kültürel kimliklere olan ilgiyi arttırması kaçınılmaz olmuştur. Bunun sonucu, yeni bir ilişki ağının ortaya çıktığı postmodern bir döneme geçilmesi olmuştur.

Postmodernist kuramcıların yanılgısı, gerçekleştiğini düşündükleri tarihsel dönüşümü kültürel sahadan hareketle aç1klayarak, ekonomik ve politik alandaki çözülmemiş çelişkilerin varlığını ihmal etmeleridir. Ekonomik ve politik sahalardaki gelişmeleri analiz etmekten kaçınarak gündelik yaşam üzerinden çıkarımlar yapmak postmodernizmin modernliğin sonu iddiasını temelden yoksun bırakmaktadır. Yeni bir tarihsel çağın 
başladığının savunulması insan sahalarının bütününde meydana gelen değişimleri ortaya koymayı gerekli kılar.

Postmodernistlerin salt kültürel sahaya odaklanarak diğer kurumsal sahalardaki gelişmeleri ihmal etmelerinin yanlış bir çıkarım olduğunu ortaya koyan en güçlü analiz Alman sosyal teorisyen Jürgen Habermas'tan gelmiştir. Habermas, modernliğin tarihi boyunca aklın araçsal olarak kullanımının egemen olması nedeniyle ekonomi ile politikadan oluşan ve araçsal aklı kullanan "sistem"in kültür ile gündelik yaşama ilişkin olan "hayat alanı"nı kolonize ettiğini iddia etmektedir. $\mathrm{Bu}$ nedenle Habermas modernliğin aşıldığından ziyade bir kriz içinde olduğunu vurgulamaktadır (Habermas, 2001). Bununla birlikte, bu krizi aşmayı sağlayacak kaynaklar modernliğin içinde mevcuttur. Modernliğin temelini oluşturan Aydınlanma kültürel sahanın özerkliğini ön plana çıkarmaktadır. Dolayısıyla, Aydınlanma öznelerin özerk eylemlerinin ortaya çıkmasını sağlayacak rehberi oluşturmaktadır. Öznelerin bir araya gelerek iletişimsel eylemde bulunmaları hayat alanını sistemin kolonizasyonundan kurtaracak ve kendi sorunlarını çözmelerini sağlayacaktır. $\mathrm{Bu}$ nedenle, modernlik Aydınlanma'nın tamamlanmamış bir projesidir (Habermas, 1990).

Habermas'ın gösterdiği gibi, postmodernizm Aydınlanma'nın yol göstericiliğini reddetmekte ve sorunları çözmeye yönelik çözümler üretmek yerine modernliği mahkum etmeye çalışmaktadır. Bu bakış açısı, sistemin yol açtığı sorunlara yönelik eleştirinin geri çekilmesine yol açarken, salt kültürel sahaya odaklanmak bu sahadaki değişimleri modernlikten bir kopuş ve postmodern bir dönemin başlangıcı olarak görmemize neden olmaktadır. $\mathrm{Bu}$ nedenle, postmodernizm modernliğe ilişkin tek yönlü bir bakış açısını temsil etmektedir. Dolayısıyla, postmodernizmin günümüz toplumuna ilişkin bütünsel bir perspektif sunamaması postmoderniteyi özgün bir çağ olarak tanımlamakta yetersiz kalmaktadır.

Postmodernizmin en temel çelişkisi, sosyal süreçleri açıklama iddiası taşıyan bir sosyal teori olmasına karşın, günümüz koşullarında sosyal teorinin toplumsal yaşamı temsil etme özelliğini kaybettiğini ileri sürmesidir. Böylece, postmodernizm bir sosyal teori olarak kendi kendini geçersiz kılmaktadır. $\mathrm{Bu}$ yaklaşımın nedeni, bir kolektivite olarak toplumun ortadan kalktığ düşüncesidir. Sosyolojinin araştırma nesnesi toplum olduğuna göre, toplumun 
sonu sosyolojinin de sonudur. Dolayısıyla, postmodern dönemin varlığ 1 onaylanırsa, toplum-sonrası bu gerçeklikte toplumsal yaşamı araştırmak anlamsız bir uğraş olacaktır.

\section{KAYNAKÇA}

Adanır, O. (2004). Baudrillard'in Simülasyon Kurami Üzerine Notlar ve Söyleşiler. İzmir: Dokuz Eylül.

Anderson, P. (2002). Postmodernitenin kökenleri. Elçin Gen (Çev.). İstanbul: İletişim.

Baudrillard, J. (2002). Simgesel Değişs Tokuş ve Ölüm. Oğuz Adanır (Çev.). İstanbul: Boğaziçi Üniversitesi.

Baudrillard, J. (2003a). Simülakrlar ve Simülasyon. Oğuz Adanır (Çev.). Ankara: Doğu Batı.

Baudrillard, J. (2003b). Sessiz Ylğınların Gölgesinde: Toplumsalın Sonu. Oğuz Adanır (Çev.). Ankara: Doğu Batı.

Best, S., Kellner, D. (1998). Postmodern Teori. Mehmet Küçük (Çev.). İstanbul: Ayrint1.

Callinicos, A. (2001). Postmodernizme Hayır. Şebnem Pala (Çev.). Ankara: Ayraç.

Debord, G. (2006). Gösteri Toplumu. Ayşen Ekmekçi \& Okşan Taşkent (Çev.). İstanbul: Ayrıntı.

Deleuze, G., Guattari, F. (1990). Kapitalizm ve Şizofreni: Cilt 1. Ali Akay (Çev.). İstanbul: Bağlam.

Eisenstadt, S. N. (2007). Modernleşme Başkaldırı ve Değişim. Ufuk Coşkun (Çev.). Ankara: Doğu Batı.

Featherstone, M. (2005). Postmodernizm ve Tüketim Kültürü, Mehmet Küçük (Çev.). İstanbul: Ayrınt1.

Fukuyama, F. (1999). Tarihin Sonu ve Son İnsan. Zülfü Dicleli (Çev.). İstanbul: Gün.

Habermas, J. (1990). Modernlik: Tamamlanmamış Bir Proje. Gülengül Naliş (Çev.). N. Zeka. (der.), Postmodernizm içinde (ss. 31-44). İstanbul: Kiyı.

Habermas, J. (2001). Illetişimsel Eylem Kuramı. Mustafa Tüzel (Çev.). İstanbul: Kabalc1. 
Harvey, D. (2010). Postmodernliğin Durumu. Sungur Savran (Çev.). İstanbul: Metis.

Heller, A., Feher, F. (1993). Postmodern Politik Durum. Şükrü Argın \& Osman Akınhay (Çev.). Ankara: Öteki.

Jameson, F. (2004). Biricik Modernite. Sami Oğuz (Çev.). Ankara: Epos. Jameson, F. (2005). Kültürel Dönemeç. Kemal İnal (Çev.). Ankara: Dost. Jameson, F. (1990). Postmodernizm ya da Geç Kapitalizmin Kültürel Mantığı. Dumrul Sabuncuoğlu (Çev.). N. Zeka. (der.), Postmodernizm içinde (ss. 59-116). İstanbul: Kiy1.

Kellner, D. (2000). Toplumsal Teori Olarak Postmodernizm: Bazı Meydan Okumalar ve Sorunlar. Mehmet Küçük (Çev.). M. Küçük (der.), Modernite Versus Postmodernite içinde (ss. 367-404). Ankara: Vadi.

Kumar, K. (1999). Çağdaş Dünyanın Yeni Kuramları: Sanayi Sonrası Toplumdan Post-Modern Topluma. Mehmet Küçük (Çev.). Ankara: Dost.

Lyotard, J. F. (2000). Postmodern Durum. Ahmet Çiğdem (Çev.). Ankara: Vadi.

Mandel, E. (2008). Geç Kapitalizm. Candan Badem (Çev.). İstanbul: Versus Kitap.

Rorty, R. (2000). Habermas, Lyotard ve Postmodernite. Mehmet Küçük (Çev.). M. Küçük (der.), Modernite Versus Postmodernite içinde (ss. 262-281). Ankara: Vadi.

Rorty, R. (2006). Felsefe ve Doğanın Aynast. Funda Günsoy Kaya (Çev.). İstanbul: Paradigma.

Sarup, M. (2004). Post-yapısalcılık ve Postmodernizm. Abdülbaki Güçlü (Çev.). Ankara: Bilim ve Sanat.

Weber, M. (2012). Ekonomi ve Toplum. Latif Boyacı (Çev.). İstanbul: Yarın. Vattimo, G. (1999). Modernliğin Sonu. Şahabettin Yalçın (Çev.). İstanbul: İz. 